\author{
ks. Janusz Królikowski \\ Uniwersytet Papieski Jana Pawła II w Krakowie \\ ORCID: 0000-0003-3929-6008; e-mail: jkroliko@poczta.onet.pl \\ https://doi.org/10.4467/25443283SYM.20.001.12118
}

\title{
INTRONIZACJA NAJŚWIĘTSZEGO SERCA JEZUSA I JEJ ZNACZENIE TEOLOGICZNE
}

\section{ENTHRONEMENT OF THE SACRED HEART OF JESUS AND ITS THEOLOGICAL MEANING}

\begin{abstract}
Abstrakt
Zadaniem teologii jest m.in. dostarczanie odpowiednich uzasadnień dla tego, czym żyje pobożność chrześcijańska. $Z$ tej racji podejmujemy próbę określenia specyfiki aktów oddania, poświęcenia i intronizacji, do których zachęca się w ramach kultu Najświętszego Serca Jezusa. Wydaje się, iż swoją logiką wewnętrzną są one najbliższe ślubom należącym do tradycyjnych aktów religijnych. Wierzący podejmuje w nich wobec Boga osobiste zobowiązanie do spełnienia określonego działania, którego przedmiotem jest jakieś dobro. W wymienionych aktach chodzi o podobne działanie. Usytuowanie w tej perspektywie wymienionych aktów nadaje im znaczącą nośność religijną, a tym samym pokazuje, że mogą one rzeczywiście przyczyniać się do integracji religijnej wierzącego.

Słowa kluczowe: ślub, oddanie, poświęcenie, intronizacja, religijność, zobowiązanie
\end{abstract}




\section{Abstract}

The goal of theology is to present, among others, the adequate explanation for the Christian piety. For that reason the attempt is made to define specificity of the acts of offering, dedication and enthronement to which we are encouraged within the cult of the Sacred Heart of Jesus. It seems that with its internal logic they are the closest to the religious vows themselves traditional religious acts. The believer takes up through them in front of God his or her personal commitment to follow particular behaviour, involving certain good. In above acts point is to create a similar effect. Placing the above acts in that perspective brings about a deeply religious meaning and additionally shows that they can profoundly contribute to the building of the integrity of the believer.

Keywords: vow, dedication, commitment, enthronement, religiousness, obligation

„Ten, który ci podpowiedział złożenie ślubów, będzie cię wspomagał. Szczęśliwa to konieczność, która przymusza do tego, co lepsze”. św. Augustyn ${ }^{1}$

W żywej pobożności Kościoła, zarówno w Polsce, jak i w wielu innych krajach, zwłaszcza od XIX wieku zyskały na znaczeniu praktyki indywidualne i wspólnotowe, które nazywa się ogólnie aktami oddania lub aktami poświęcenia. Ich geneza jest bardzo odległa w czasie, sięgając w zasadzie wczesnego średniowiecza. Akty tego typu były kierowane na początku głównie do Maryi, Matki Bożej, w propagowanych już od końca XVI wieku przez jezuitów sodalicjach mariańskich, podobny charakter posiadał tzw. dyplom sodalisa. W Polsce szczególnego znaczenia nabrały śluby Jana Kazimierza (1656 rok), a potem rocznicowa praktyka ich odnawiania, za którą poszły następnie Jasnogórskie Śluby Narodu Polskiego (1956 rok). Na pewno w polskiej praktyce rozmaitych aktów maryjnych trzeba pamiętać o Akcie oddania Polski w macierzyńska

1 Augustyn, Epistula 127, 8: PL 33, 487. 
niewole Maryi, Matki Kościoła, za wolność Kościoła Chrystusowego (1966 rok). Święty Jan Paweł II wniósł do pobożności kościelnej, wyrastające w znaczącej mierze z jego osobistego doświadczenia maryjnego, „akty zawierzenia" Maryi, ale posiadają one trochę inne znaczenie niż akty oddania czy poświęcenia, ponieważ zawierzenie jest przede wszystkim aktem uznania całkowitej zależności od Boga przez Maryję, podczas gdy akty oddania i poświęcenia polegają na ogół na przyjęciu jakiegoś zobowiązania względem Boga $^{2}$.

Do maryjnych aktów oddania i poświęcenia, zwłaszcza pod wpływem św. Małgorzaty Marii Alacoque (1647-1690), doszły następnie akty oddania i poświęcenia Najświętszemu Sercu Jezusa, które osiągnęły szczególny zasięg i wpływ w XIX wieku wraz z naciskiem kładzionym na całościowo i coraz dojrzalej rozumiany kult Serca Jezusowego w Kościele. Ciągle żywym wyrazem tej praktyki jest Akt poświęcenia rodzaju ludzkiego Najświętszemu Sercu Pana Jezusa, wprowadzony przez papieża Leona XIII i potwierdzony przez wszystkich kolejnych papieży. Na początku XX wieku, zwłaszcza pod wpływem wielkiego apostoła kultu Serca Jezusa o. Mateo Crawley-Boeveya (1875-1960), została wprowadzona i stopniowo rozpowszechniła się praktyka intronizacji Najświętszego Serca Jezusa, która szeroko utrwaliła się zwłaszcza jako pobożna praktyka rodzinna (intronizacja w rodzinie), a dzisiaj rozwija się ona $w$ dalszym ciągu jako intronizacja społeczna, z pewnym naciskiem kładzionym przez rozmaite ruchy i środowiska w Polsce także na intronizację narodową. Za wyraz tych tendencji należy uznać Jubileuszowy akt przyjęcia Jezusa Chrystusa za Króla i Pana, który miał miejsce w Krakowie-Łagiewnikach, 19 listopada 2016 roku$^{3}$.

Wspólnym elementem tych wszystkich aktów religijnych jest to, że zawiera się $\mathrm{w}$ nich podjęcie zobowiązania do pewnego działania, które podejmuje wierzący indywidualnie bądź też taka czy inna wspólnota kościelna, mając na względzie rozwój swojego życia chrześcijańskiego

2 Por. J. Królikowski, Bogurodzica Dziewica, Niepokalanów 2013, s. 143-160.

${ }^{3}$ Por. M. Chmielewski, J. Kobienia, A. Flaga (red.), Trzeba, aby Chrystus królował. Ogólnopolskie obchody rocznicy proklamacji Jubileuszowego aktu przyjęcia Jezusa Chrystusa za Króla i Pana, Kraków-Łagiewniki, 17-19 XI 2017 r., Kraków 2018. 
albo w całości, albo w określonym aspekcie. Biorąc pod uwagę zasięg i wielość tych aktów, zasługują one niewątpliwie na uwagę teologa i na próbę lepszego ich uzasadnienia teologicznego. Jest to tym ważniejsze, że niejednokrotnie można spotkać się ze stawianym przez wiernych bardzo podstawowym pytaniem, jaki jest sens tych aktów i co one właściwie wnoszą do życia chrześcijańskiego. Trzeba przyznać, że tego typu pytania są jak najbardziej uzasadnione, gdyż rzeczywiście poświęca się niewiele uwagi teologicznemu i systematycznemu uzasadnieniu podejmowania rozmaitych aktów, tym bardziej, że pojawiają się stale nowe (np. 3 maja 2020 roku nastąpiło zawierzenie ojczyzny Najświętszemu Sercu Pana Jezusa i Matce Bożej, Królowej Polski). Tymczasem dopiero w takim uzasadnieniu najlepiej ukazuje się ich znaczenie religijne oraz możliwy wpływ zarówno na życie indywidualne wierzącego, jak i na życie eklezjalne i społeczne.

Mając więc na uwadze ten fakt, zamierzam tutaj podjąć zagadnienie rozmaitych aktów, które są dokonywane w perspektywie zobowiązania się do czegoś przed Bogiem. Do takich aktów należy także intronizacja Najświętszego Serca Jezusa, która w ostatnim czasie na nowo weszła do języka religijnego i w różnych sytuacjach przyciąga uwagę. Pomijam w tym miejscu problematykę historyczną intronizacji, która była już wielokrotnie podejmowana i na ogół jest znana ${ }^{4}$.

\section{Zobowiązanie przed Bogiem i ze względu na Boga}

W celu odpowiedniego zrozumienia i uzasadnienia wszelkich zobowiązań, które podejmuje człowiek przed Bogiem, a które wyrażają się we wspomnianych wyżej aktach religijnych, wydaje się, że trzeba przede wszystkim sięgnąć do teologii ślubu, oznaczającego właśnie wyrastające z wiary zobowiązanie się do czegoś przez wierzącego wobec Boga i ze względu na Niego. Praktyka składania ślubów została w ostatnim czasie mocno zawężona. Ogranicza się ona najczęściej do przyrzeczeń chrzciel-

4 Por. J. Królikowski, Umiłował nas ludzkim sercem. Teologia i kult Najświętszego Serca Jezusa (1765-2015), Kraków 2014, s. 162-211. 
nych, do składania ślubu w czasie zawierania sakramentu małżeństwa bądź też do ślubowania rad ewangelicznych w rozmaitych formach życia konsekrowanego. Zawężenie tego typu nie ma uzasadnienia, ponieważ praktyka składania ślubów należy do starożytnych i podstawowych praktyk religijnych, które mogą dotyczyć bardzo zróżnicowanych „działan”, zarówno indywidualnych, jak i zbiorowych, podejmowanych przez wiernych ze względu na Boga ${ }^{5}$.

"Złóżcie śluby i wypełniajcie je przed Panem, Bogiem waszym” (Ps 76[75],12) - ta zachęta psalmisty stanowi jakby streszczenie przekonania starotestamentowego, że składane śluby stanowią integralną część religijności oraz jej bardzo szczególny i uzasadniony wyraz. W swojej właściwej strukturze są one zakorzenione w teologii przymierza, w ramach którego lud składał przed Bogiem uroczyste zobowiązanie do jego wypełnienia: „Wszystkie słowa, jakie powiedział Pan, wypełnimy” (Wj 24,3). Każdy ślub składany przez wierzącego, w nawiązaniu do tego pierwotnego zobowiązania, staje się wyznaniem Boga życzliwego człowiekowi oraz Boga wspomożyciela, wyraża się w nim dziękczynienie i uwielbienie Boga. Niejednokrotnie ślub jest synonimem ofiary, a nawet czymś większym niż ofiara, gdy jest składany w pełni świadomie i dobrowolnie oraz dotyczy szczególnie ważnego dobra. Księgi mądrościowe są wprawdzie wstrzemięźliwe, jeśli chodzi o składanie ślubów, gdyż mędrcy żydowscy realistycznie zdają sobie sprawę, że często są one składane bez odpowiedniego przemyślenia (np. Jefte), a potem niestety brakuje zdecydowanego zaangażowania w ich wypełnianiu6. W Nowym Testamencie nie ma odrębnego nauczania na temat składania ślubów - została w nim przyjęta perspektywa starotestamentowa i zyskała ona potem trwałe potwierdzenie w praktyce Kościoła.

Nie wchodząc w rozmaite, niekonieczne w tym miejscu szczegóły zagadnienia, zwrócimy jedynie uwagę na teologiczną specyfikę ślubu i jego bardzo szczególne znaczenie religijne. Wydaje się, że dla naszego zagadnienia wystarczające będzie wykorzystanie tego, co na temat ślubu

5 Por. Katechizm Kościoła katolickiego, Poznań 2002 (dalej: KKK), 2001-2003.

6 Por. C. A. Keller, ndr - far voto, w: E. Jenni, C. Westermann, Dizionario teologico dell'Antico Testamento, t. 2, Casale Monferrato 1982, kol. 36-39. 
syntetycznie wyjaśnia św. Tomasz z Akwinu w traktacie $O$ doskonałości $\dot{z} y$ cia duchowego ${ }^{7}$. Podejmuje on $\mathrm{w}$ nim zagadnienie ślubu w relacji do pytania, które możemy uznać za nadzwyczajnie współczesne, a mianowicie: Co jest lepsze, czy to, co jest dobrowolne - chodzi o jakieś dobro - czyli spełnione „z własnego wyboru”, czy coś, co musi się wypełnić, bo jest konieczne, czyli wynikające ze ślubu lub z posłuszeństwa, a więc „pod przymusem”? Podobnie jak w czasach Akwinaty, także dzisiaj twierdzi się następująco: „Coś jest tym bardziej godne pochwały i tym

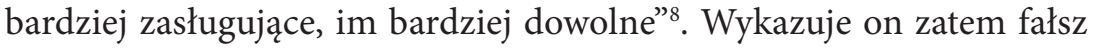
tej tezy, a zarazem podaje odpowiedź uzasadniającą wartość składanych ślubów.

Święty Tomasz z Akwinu najpierw ukazuje więc specyfikę ślubu w dziedzinie religijnej oraz określa jego najbardziej właściwe aspekty. W swoim uzasadnieniu wychodzi od argumentu biblijnego, którego dostarcza mu wyżej cytowany Psalm 76[75],12. Bóg nie nakazuje składać ślubów, choć je wyraźnie doradza, ale potem, gdy zostaną już złożone, domaga się ich wypełnienia. Oczywiście przedmiotem ślubu może być jakiekolwiek dobro, zarówno nakazane przez Boga, jak i dobro doradzane, ale człowiek w pewnych okolicznościach decyduje się bardziej bezpośrednio i zasadnie zobowiązać do wypełnienia zarówno jednego, jak i drugiego. Ślub może więc zarazem odnosić się do przykazania i do rady, zależnie od dobra, do którego się odnosi, ale najważniejsze jest to, że ze względu na dokonany osobiście wybór podnosi on rangę ślubowanego dobra. Wynika to $\mathrm{z}$ faktu, że ostatecznie ślub opiera się na poszukiwaniu „większej miłości”, a więc tym samym bardziej zbliża do Boga - jest aktem ludzkiej miłości, która wyraża się w swoim dynamizmie i chce wzrastać. Ta większa miłość w sposób szczególny ukazuje się, wtedy gdy człowiek ślubuje to, co jest przedmiotem rady, a nie tylko przykazania, ponieważ chodzi w tym przypadku o „lepsze dobro”. Odnosi się to do każdego dobra, które stosownie do okoliczności może wybrać człowiek, a następnie ten wybór potwierdzić ślubem. Szczególnego znaczenia w tym przy-

7 Por. Tomasz z Akwinu, O doskonałości życia duchowego, w: tenże, Dzieła wybrane, tłum. J. Salij i in., Kęty 1999, s. 364-436.

8 Tamże, s. 386. 
padku nabiera więc motyw, ze względu na który człowiek składa ślub. Odwołując się do przykładu dziewictwa, św. Tomasz z Akwinu podkreśla, że jest ono "godne zalecenia dopiero na mocy ślubu", czyli ostatecznie na mocy miłości. Dotyczy to jednak - jak już wyżej zaznaczono każdego dzieła, które człowiek decyduje się poświęcić Bogu. Ślub dokonuje niejako podniesienia rangi aksjologicznej działań, do których się odnosi.

Kolejnym argumentem wzmacniającym znaczenie ślubu jest łączenie ze sobą większej liczby dóbr, gdyż „każde dobro skończone zyskuje na tym, jeśli do niego dołączyć inne dobro"10. Święty Tomasz z Akwinu jest w tym przypadku bardzo otwartym teologiem, ponieważ zwraca uwagę, iż „sama obietnica dobra niewątpliwie jest jakimś dobrem”"11, a więc sam zakorzeniony w woli zamiar zyskania pewnego dobra dokonuje połączenia go z dobrem pierwotnym, stanowiącym przedmiot ślubu. Już sama obietnica dążenia do dobra nie jest więc bez znaczenia w perspektywie odniesienia do Boga, a tym samym także osobistej świętości. Akwinata w swojej wizji ślubu, opierając się zresztą na wcześniejszej tradycji, wyjątkowo dowartościowuje wolę człowieka, która odgrywa kluczową rolę w wybieraniu dobra i w jego dowartościowaniu ze względu na miłość i jej rozwój. Odbija się w tym zasadnicze przekonanie św. Tomasza z Akwinu, które posiada rangę zasady uniwersalnej, że „zbawienie jest w woli”.

Do tych podstawowych argumentów za składaniem ślubów dochodzą dalsze, które dokonują niejako ich uszczegółowienia i wzmocnienia. Idąc po linii wolitywnej, Akwinata podkreśla, że w ramach ślubu człowiek ofiaruje Bogu nie tylko to, co czyni, czyli sam materialny czyn, ale przede wszystkim samą „swoją zdolność czynienia” ${ }^{12}$, czyli oferuje $\mathrm{w}$ gruncie rzeczy swoją wolę, a więc samego siebie. Można w tym przypadku, nawiązując do języka biblijnego - zawsze bliskiego Akwinacie - powiedzieć, że człowiek w ślubie ofiaruje Bogu swoje serce (por. Prz 23,26), to znaczy centrum swojego bytu i swojej osobowości wraz

\footnotetext{
9 Tamże, s. 387.

10 Tamże.

11 Tamże.

12 Tamże.
} 
z całym jego dynamizmem. Na tym gruncie duchowym rodzą się w człowieku nowe zobowiązania, a tym samym: „, nie może nie czynić tego, czego przedtem mógł godziwie nie czynić" ${ }^{13}$. Mamy w tym przypadku do czynienia z wyrażeniem dążenia do pełni działania zakorzeniającego się w poszukiwanej przez człowieka pełni swojego bytu. Ślub kształtuje więc w człowieku jakby podstawową opcję egzystencjalną, wpływowo ukierunkowującą jego wybory i podejmowane działania, która jakby nakłada się na tę opcję, którą konstytuuje w nim wiara.

Taki sposób działania sprawia następnie, że „wola jest utwierdzona w dobrym"14. Z samego już psychologicznego punktu widzenia ślub dokonuje wzmocnienia woli, ponieważ ukierunkowuje ją na bardzo określone dobro i domaga się bardziej jednoznacznego szukania go i wybierania. Dokonuje on konsolidacji wewnętrznej, której dobro jest konstytutywnym elementem. Mamy tu do czynienia z koncepcją „woli utwierdzonej", która doznaje umocnienia przez wiernie i konsekwentnie wybierane dobro, do czego zobowiązuje złożony ślub. Koncepcja ślubu w ujęciu św. Tomasza z Akwinu nawiązuje więc wyraźnie do biblijnej koncepcji wierności, która zakłada stałość w wybieraniu pewnych określonych, szczególnie wyższych dóbr, stając się mocnym oparciem wewnętrznym człowieka, a zwłaszcza bezpośrednim potwierdzeniem jego wiary i religijności.

W końcu Akwinata łączy ślub z cnotą, stanowiącą właściwe kryterium i punkt odniesienia $\mathrm{w}$ jego spojrzeniu na ludzkie działanie, podkreślając, że „czyn jest godzien tym większej chwały, z im wznioślejszej wypływa cnoty" ${ }^{15}$. Jak na początku wyszedł on od uznania wartości motywacji w składanym ślubie, tak w tym miejscu ta motywacja zostaje nie tylko skonkretyzowana w cnocie, ale zostaje pokazane, że zyskuje ona właściwe znaczenie, gdy urzeczywistnia się ze względu na cnotę wyższą. Jest to spójne z dynamizmem życia cnotliwego, w które jest wewnętrznie wpisane dążenie do przekroczenia tego, co zostało już osiągnięte. Ślub nadaje działaniu ludzkiemu najwznioślejsze znaczenie,

\footnotetext{
13 Tamże.

14 Tamże, s. 388.

15 Tamże.
} 
ponieważ stanowi on „czysty akt kultu Bożego”, a więc odnosi się do cnoty religijności, nad którą nie ma nic wznioślejszego ${ }^{16}$. Dzieje się tak, dlatego że łączy ona człowieka z jego celem ostatecznym, którym jest jedynie Bóg. Ślub sprawia, że cnotliwe działanie człowieka doznaje szczególnego wyniesienia. Ponieważ jest on składany ze względu na Boga, dlatego działanie człowieka odnoszące się do ślubu nabiera znaczenia religijnego, a tym samym także duchowego, gdyż za jego pośrednictwem dokonuje się efektywne zbliżenie człowieka do Boga jako jego celu, a to jest najważniejsze z egzystencjalnego punktu widzenia.

Podjęty systematyczny wykład na temat ślubu św. Tomasz z Akwinu w zakończeniu ponownie - jak uczynił na początku - odnosi do źródeł biblijnych, dokonując w ich perspektywie podsumowania zaproponowanego przez siebie ujęcia. Tym razem - w świetle tego, co zostało powiedziane - powołuje się na św. Pawła, który w Pierwszym Liście do Koryntian zaleca: „Ubiegajcie się o lepsze dary” (12,31). Ślub jest takim lepszym darem, ponieważ dzięki niemu wierzący może wznieść się „na wyższy stopień doskonałości” ${ }^{17}$, jak pokazują teologiczne racje jego składania omówione przez Akwinatę. Potwierdza to także żywa praktyka Kościoła, który zaleca śluby, a to zalecenie niejako kodyfikuje i wzmacnia, obdarzając je odpustami i przywilejami, aby podnosić poziom życia duchowego wierzących, a tym samym także podnosić duchowo cały Kościół. Ślub posiada zatem pewną i spójną weryfikację biblijną i eklezjalną, która zarówno gwarantuje jego autentyczność, jak i zachęca do kontynuowania tej pobożnej praktyki.

W dalszej części swojego wykładu teologii ślubu św. Tomasz z Akwinu wykazuje, że nie ma sprzeczności między ślubem i dobrowolnością czynu. Ślub przyczynia się do tego, że to, co zostało ślubowane, wypełnia się „ochoczo"18, a więc nadaje dynamizm ludzkiemu działaniu. Nawet jeśli ślubowane dzieło jest wypełniane pod pewnym naciskiem - złożonemu ślubowi nie musi zawsze towarzyszyć jakiś łatwy entuzjazm - to i tak jest ono dobre, ponieważ chodzi o czyn „bardziej godny

\footnotetext{
16 Por. tamże.

17 Tamże.

18 Tamże.
} 
chwały i więcej zasługujący"19. Decyduje o tym także wola, która spełnia czyn ze względu na ślub lub posłuszeństwo, które w każdym przypadku pozostaje najwznioślejszym aktem duchowym, stanowiącym niejako wzniosłą syntezę doświadczenia religijnego ${ }^{20}$. Ten fakt konkretyzuje się i dopełnia w tym, że ślub jest spełniany ze względu na Boga, a to podnosi rangę pokonywania własnej woli, a więc przekraczania siebie w relacji do Niego.

Na uwagę zasługuje w tym miejscu jeszcze jedna kwestia, na którą zwraca uwagę Akwinata, realistycznie zdając sobie sprawę, że człowiek nie zawsze dochowuje woli wypełnienia złożonego ślubu. W takim przypadku człowiek jest „u Boga niszczycielem ślubu i fałszerzem posłuszeństwa, Bóg jest bowiem sędzią serc"21. Ma to miejsce, gdy spełnia ślub tylko z ludzkich i zewnętrznych pobudek, a więc nie ze względu na Boga, czyli nie z motywacji religijnej. W takim przypadku jest to rzeczywiście tylko konieczność, ale mimo to „nie ślubował na próżno (...), bo zostanie mu przywrócona zasługa, jeśli pożałuje przewrotności”22. Decydujący o ludzkim działaniu akt woli także w tym przypadku wyraźnie dochodzi do głosu, dowartościowując to, co rodzi się w człowieku i zawsze może zostać udoskonalone w perspektywie pobożności i jej konkretnego wyrażania się.

Podsumowując przywołane wątki teologii ślubu w ujęciu św. Tomasza z Akwinu, możemy powiedzieć, że w ten akt religijny wpisany jest bardzo szczególny dynamizm duchowy, który jest w stanie wyzwolić w człowieku i nadać szczególną wzniosłość religijną jego działaniu. Z tych właśnie racji, nie zawsze może tak jasno wyłożonych, ślub odgrywa tak ważną rolę w duchowym doświadczeniu w Kościele i może okazać się bardzo inspirujący także dla duchowości i pobożności w naszych czasach.

19 Tamże, s. 389.

${ }^{20} \mathrm{Na}$ temat syntetyzującego znaczenia posłuszeństwa w wierze por. Tomasz z AKWINU, Summa theologiae, II-II, q. 186 a. 5 ad 4: „Votum obedientiae ad religionem pertinens, se extendit ad dispositionem totus humanae vitae et secundum hoc votum obedientiae habet quamdam universalitatem".

21 Tomasz z Akwinu, O doskonałości życia duchowego, dz. cyt., s. 389.

22 Tamże. 


\section{Oddanie, poświęcenie, intronizacja}

Elementy teologii ślubu, które przywołaliśmy, nawiązując do ujęcia św. Tomasza z Akwinu, mogą zostać efektywnie wykorzystane do uchwycenia zasadniczego znaczenia teologicznego różnego rodzaju aktów religijnych, zwłaszcza takich jak akty oddania, poświęcenia i intronizacji, obecnych i stosowanych w kulcie Najświętszego Serca Jezusa, jak również w różnych formach kultu Matki Bożej. Ich podstawowe pokrewieństwo ze ślubem wynika $z$ tego, że zawierają zobowiązanie się do podejmowania pewnych działań nastawionych na realizację dobra, bardziej lub mniej określonego i uszczegółowionego. Wpisują się one także w ogólną perspektywę życia religijnego, dokonując jego wewnętrznej unifikacji przez odpowiednie umotywowanie go teologiczne i przez skonkretyzowanie go w odniesieniu do podejmowanych działań. Oczywiście ranga teologiczno-kanoniczna ślubu jest o wiele większa niż prywatnego czy nawet wspólnotowego aktu religijnego, ale w przypadku aktów, o których mówimy, jest ważne i inspirujące przede wszystkim to, że opierają się one właściwie na takiej samej logice teologicznej i na bardzo podobnym znaczeniu duchowym.

Nawiązując do kolejnych teologicznych właściwości ślubu, możemy więc najpierw wskazać, że wszelkiego typu akty oddania, poświęcenia czy intronizacji są tymi aktami, za pośrednictwem których wierzący - dojrzewając zasadniczo w cnotach teologalnych i nie zadowalając się osiągniętym realnie stanem duchowym - wchodzi na drogę poszukiwania „większej miłości”. Miłość w rozumieniu chrześcijańskim jest rzeczywistością osobową, która nigdy nie zatrzymuje się w swojej wędrówce, ale jest zawsze otwarta na wzrost i przekraczanie siebie. Zgodnie z tradycyjnym doświadczeniem chrześcijańskim można powiedzieć, iż „miarą miłości jest to, że nie ma żadnej miary”23. Jest jak najbardziej zrozumiałe, że wierzący rozwijając się duchowo, zdaje sobie sprawę z tego, że jest wezwany do większej miłości, w związku z czym podejmuje poszukiwanie takiego „działania”, a więc także takiego ukierunkowania na większe dobro, przez które mógłby wyrazić tę większą miłość. Jest w tym coś do-

${ }^{23}$ Por. KKK 2028 (cytat ze św. Grzegorza z Nyssy). 
głębnie naturalnego, o czym świadczy choćby dynamika miłości opisana w starotestamentowej Pieśni nad Pieśniami. Wybór konkretnego działania - ponieważ miłość jest działaniem - w którym ta wewnętrzna dynamika może się wyrazić, staje się następnie najlepszym sposobem rozwoju duchowego i udzielenia odpowiedzi na wewnętrzny imperatyw.

Patrząc na życie świętych, a zwłaszcza czytając ich dzienniki duchowe, na ogół z łatwością zauważamy, że w pewnych momentach wędrówki duchowej, po przebyciu określonego etapu oraz osiągnięciu i utrwaleniu wyższego poziomu rozwoju, dochodzą oni do podjęcia jakby rezolucji duchowej, której efektem są składane zobowiązania dotyczące pójścia dalej; następuje u nich konkretyzacja nabytych doświadczeń, przekładających się na nową gorliwość. To doświadczenie wyraża się często w nowych ślubach (np. składają ślub gorliwości), formułowanych aktach oddania czy poświęcenia, bądź też w podejmowaniu określonych postanowień. Taki proces duchowy możemy zauważyć na przykład u św. Małgorzaty Marii Alacoque, której osobisty akt poświęcenia Najświętszemu Sercu Jezusa wyrasta z uprzednio przeżytej i doprowadzonej do dojrzałości potrzeby wyrażenia pragnienia dążenia do większej miłości. Podobne doświadczenie możemy znaleźć w życiu służebnicy Bożej Rozalii Celak, która w takim duchu dokonuje aktu osobistej intronizacji Najświętszego Serca.

Dokonywane akty są więc wyrazem osiągniętej dojrzałości duchowej, która przekłada się potem na nowe, skonkretyzowane zobowiązania, aby zdążać do większej miłości, wybierając czynienie pewnego konkretnego dobra, które jest drogą prowadzącą do osiągnięcia zamierzonej większej miłości. Takie akty mogą stać się również programem szerszego działania i składania świadectwa, aby prowadzić innych do przeżytej i doświadczonej przez siebie miłości.

Elementem niejako organizującym wewnętrznie i ukierunkowującym akty oddania czy poświęcenia jest określone w nich „lepsze dobro”, które zamierza się osiągnąć. Ich przedmiotem nie jest to, co łączy się z przykazaniem czy wcześniejszym zobowiązaniem, ale oznaczają one szukanie czegoś więcej w życiu duchowym i w podejmowanym oddziaływaniu. Jako przykład może posłużyć kult Najświętszego Serca Jezusa. Sam z siebie nie należy do zwyczajnej wędrówki duchowej i pobożnej chrześcijanina, na którą składają się cnoty teologalne wiary, nadziei 
i miłości, sakramenty i modlitwa. Ten kult jest raczej konkluzją dojrzałego przeżywania elementów zwyczajnych, ale jest także ich przekroczeniem, stając się czymś dodatkowym, a nawet większym, prowadzącym na wyższy poziom życia duchowego. $Z$ tej racji sytuuje się on na linii „lepszego dobra”, ponieważ w pewien sposób niejako „odgórnie” dokonuje uporządkowania życia chrześcijańskiego, jego właściwego ukierunkowania, a także dodatkowo je uszlachetnia.

Akt oddania czy poświęcenia, łączący się z tym rodzajem kultu i wpisujący się w jego żywą realizację, dokonuje jego osobistej ratyfikacji oraz przyjęcia za element własnej wędrówki duchowej. Dopóki nie stanie się on przeżytym doświadczeniem, nawet stanowiąc czcigodny „depozyt łaski”, jak nazwał go papież Pius XII, nie wywiera bezpośredniego wpływu na życie religijne chrześcijanina.

Rozmaite akty, o których tutaj mówimy, są więc sposobami wzbudzania osobistego zaangażowania i rozwoju duchowego, zatem dokonuje się za ich pośrednictwem także podniesienie życia religijnego na wyższy poziom, a następnie umacnianie go w relacji do pewnych kluczowych treści i wartości religijnych. Wydaje się, że tego typu doświadczenie rzeczywiście towarzyszy wszystkim, którzy takie akty podejmują, angażują się w ich realizację, a więc czynią je treścią osobistych doświadczeń. W przypadku kultu Najświętszego Serca Jezusa można zauważyć, że jego wybitni przedstawiciele takie akty rzeczywiście mocno wpisywali w swoje życie, czyniąc je podstawowymi momentami weryfikującymi ich wędrówkę duchową.

Wynika to przede wszystkim z tego, że - jak zauważył św. Tomasz z Akwinu w odniesieniu do ślubu - przez wspomniane akty dokonuje się wyraźne łączenie rozmaitych dóbr duchowych w jedną całość, zwłaszcza w wymiarze wolitywnym. Warto na to zagadnienie zwrócić uwagę, ponieważ obecnie ten aspekt życia chrześcijańskiego uległ wyraźnemu pomniejszeniu na rzecz doświadczeń uczuciowych bądź emocjonalnych, których znaczenie jest bardzo ograniczone, jeśli nie wprost wątpliwe. Wola zyskania pewnego dobra jest, mówiąc językiem klasycznym, ważnym „motorem” duchowym. Dokonuje ona formującego poruszenia człowieka. Z chrześcijańskiego punktu widzenia wola odgrywa kluczową rolę w perspektywie autentycznego wyzwolenia, a tym samym tak- 
że w perspektywie zbawienia. Oczywiście wola nie jest samowystarczalna zbawczo, ale jej ruch wewnętrzny odgrywa kluczową rolę w przyjęciu łaski, a następnie w jej strzeżeniu i rozwijaniu w świętości. Akty oddania i poświęcenia spełniają więc $\mathrm{w}$ stosunku do woli rolę formującą i ukierunkowującą, a zatem wpływają także na wolność i miłość, odnosząc się tym samym do celu ludzkiego życia w aspekcie jego faktycznego osiągnięcia.

W ślubie, a także w rozmaitych aktach pobożnych, które są mu pokrewne - tzn. oparte na osobistej wolności i podejmowanych świadomie zobowiązaniach - mamy niewątpliwie do czynienia z traktowaniem wiary jako pewnej opcji egzystencjalnej, która aby taką pozostała, domaga się nieustannego potwierdzania w rozmaitych, nakładających się na nią decyzjach; zwłaszcza takich, które odnoszą ją do jej celu czy też sensu - jak dzisiaj chętnie mówimy, odwołując się do bardziej fenomenologicznego sposobu ujmowania zagadnień teologicznych. Przez każdy zobowiązujący akt, przez który wyraża się poszukiwanie większego dobra oraz opowiadanie się za nim, dokonuje się właściwe usytuowanie jego poszczególnych aspektów w relacji do całości życia chrześcijańskiego i nadanie im odpowiedniej perspektywy duchowo-teologicznej. Można by zestawić to łączenie rozmaitych aspektów życia duchowego za pośrednictwem tych aktów z tym, co II Sobór Watykański nazywa ,jednością życia”, jako ideałem, do którego powinien zmierzać chrześcijanin. Chodzi w tym przypadku o osiągnięcie wewnętrznej spójności, utrwalenie wierności i pobudzenie dążeń duchowych na gruncie autentycznej pobożności. Za św. Tomaszem z Akwinu możemy syntetycznie powiedzieć, że chodzi $\mathrm{w}$ tym przypadku o religijne utrwalenie $\mathrm{w}$ dobrym.

Niejako podsumowując omawiane tutaj znaczenie teologiczne aktów oddania, poświęcenia czy intronizacji, należy nade wszystko podkreślić, że ich najbardziej właściwą cechą jest dominująca w nich perspektywa religijna - są one wszystkie podporządkowane cnocie religijności. Stąd nazywamy je także aktami religijnymi lub pobożnymi.

Być może w tym najważniejszym punkcie podjętej tutaj refleksji teologicznej napotykamy na największe trudności. Wynikają one z niedoceniania dzisiaj cnoty religijności, czego dowodzi niewielkie zainteresowanie, z którym się spotyka, i niewielka ranga, jaką jej się nadaje w duchowości. 
Mamy tutaj do czynienia z mocnymi wpływami protestanckimi, zwłaszcza teologii liberalnej z pierwszej połowy XX wieku, która dokonała skrajnego przeciwstawienia między wiarą i religią/religijnością. Możemy je z łatwością zauważyć w polskiej teologii, duchowości czy także w katechezie. Wszystko dzieje się pod pozornie szczytnym pretekstem poszukiwania i formowania „czystej” wiary paschalnej. Nie wchodząc w szczegóły, musimy jednak zdawać sobie sprawę z istniejących trudności, które wyrażają się w pomniejszaniu znaczenia rozmaitych praktyk i aktów religijnych, w tym także aktów, o których tutaj mówimy.

Zwróćmy więc pozytywnie uwagę jedynie na fakt, że właściwie rozumiana cnota religijności spełnia rolę unifikującą i niejako totalizującą w stosunku do wszystkich relacji i aktów ludzkich ${ }^{24}$. Wynika to z samej natury tej cnoty, która oznacza osobową relację człowieka z Bogiem jako jego Stwórcą, Pojednawcą i Wypełnieniem. Cnota religijności umożliwia, aby wszystko, co zamierza człowiek, znalazło odniesienie do Boga i było czynione ze względu na Niego. Ma ona więc charakter dogłębnie teocentryczny i teocentrycznie kształtuje człowieka. Religijność jest szczególną mocą duchową, która obejmuje i łączy ze sobą akty wszystkich cnót, a czyni to ze względu na swój przedmiot, którym jest tylko i wyłącznie sam Bóg, od którego pochodzi każde dobro czynione przez człowieka. To Bóg je potem oczyszcza i w sobie dopełnia. Człowiek religijny do Boga odnosi więc wszystkie swoje możliwości i swoje zobowiązania, a tym samym otwiera się na ich dopełnienie, którego On sam w nim dokonuje. Dotyczy to w najwyższym stopniu wszystkich specjalnych aktów, które człowiek wprost podejmuje ze względu na Boga, będąc świadomym, że to On jest w nim „sprawcą i chcenia, i działania zgodnie z [Jego] wolą" (Flp 2,13).

To wszystko, co zostało tu powiedziane o osobistych relacjach i działaniach człowieka, odnosi się także do wszystkich relacji społecznych, jak religia odnosi wszystko, a więc także to, co społeczne i wspólnotowe, do Boga i ze względu na Niego uporządkowuje, gdyż On jest celem

24 Por. B. De Margerie, Mélanges anthropologiques à la lumière de saint Thomas d’Aquin, Paris 1993, s. 51-64. Autor omawia ujęcie św. Tomasza z Akwinu zawarte w Super Boetium de Trinitate, lect. I q. 1 a. 2. 
życia społecznego. Wynika z tego, że w perspektywie cnoty religijności są w pełni uzasadnione wszelkie akty religijne o charakterze wspólnotowym i społecznym i mogą sobie stawiać takie same cele.

Relacja religijna kształtowana przez ożywiane wiarą akty pobożności, w tym także akty, o których tutaj mówiliśmy, może być w pełni prawomocnie uznana za dobrowolne dążenie człowieka do osiągnięcia całkowitego wypełnienia, ponieważ wyraża on w nich zasadę swojego bytu i wszystkich dóbr, do których odnosi swoje działanie. W tych aktach urzeczywistnia się zatem uznanie prymatu Boga oraz osobiste i całkowite oddanie Mu swego życia, a zarazem zyskują aprobatę wszystkie akty, które to wyrażają i do tego zmierzają.

\section{Zakończenie}

W podjętej refleksji niewiele uwagi poświęciliśmy wprost samej tytułowej idei intronizacji Najświętszego Serca Jezusa, co nie wydaje mi się błędem metodologicznym. To, co zostało tutaj powiedziane, zwłaszcza w drugiej części, o znaczeniu aktów pobożnych, do których zaliczają się bardziej tradycyjne akty oddania i poświęcenia Najświętszemu Sercu Jezusa oraz „młodsze” akty intronizacji, sytuuje się właściwie w takiej samej perspektywie teologicznej i odpowiada takiej samej logice duchowej. Ponieważ nie zajmowano się do tej pory systematycznie tą sprawą, warto było ująć zagadnienie w nieco bardziej ogólnej i podstawowej zarazem perspektywie teologicznej, która w pełni może być zastosowana do uzasadnienia aktów intronizacji.

Właściwie należałoby teraz zająć się innym, równie ważnym zagadnieniem, a mianowicie: W jaki sposób w dzisiejszej sytuacji duchowej formować w wierzących gotowość do podejmowania takich aktów i jak wspierać ich duchowo i pastoralnie $\mathrm{w}$ ich wiernym wypełnianiu? Nie możemy założyć, że zagadnienie jest oczywiste samo przez się, ponieważ uległy wyraźnej zmianie warunki, w których żyjemy i kształtujemy nasze doświadczenia duchowe. Tym bardziej jest to ważne, że zwłaszcza podejmowanie zobowiązań w dziedzinie religijnej nie jest traktowane $\mathrm{z}$ właściwym zrozumieniem i wypełniane $\mathrm{z}$ właściwą konsekwencją. 


\section{Bibliografia}

Augustyn, Epistula 127: PL 33.

Chmielewski M., Kobienia J., Flaga A. (red.), Trzeba, aby Chrystus królował. Ogólnopolskie obchody rocznicy proklamacji Jubileuszowego aktu przyjęcia Jezusa Chrystusa za Króla i Pana, Kraków-Lagiewniki, 17-19 XI 2017 r., Kraków 2018.

Jenni E., Westermann C., Dizionario teologico dell'Antico Testamento, Casale Monferrato 1982.

Katechizm Kościoła katolickiego, Poznań 2002.

Keller C. A., ndr - far voto, w: E. Jenni, C. Westermann, Dizionario teologico dell'Antico Testamento, t. 2, Casale Monferrato 1982, kol. 36-39.

Królikowski J., Bogurodzica Dziewica, Niepokalanów 2013.

Królikowski J., Umiłował nas ludzkim sercem. Teologia i kult Najświętszego Serca Jezusa (1765-2015), Kraków 2014.

Margerie B. de, Mélanges anthropologiques à la lumière de saint Thomas d'Aquin, Paris 1993.

Tomasz z Akwinu, O doskonałości życia duchowego, w: Tomasz z Akwinu, Dzieła wybrane, tłum. J. Salij i in., Kęty 1999, s. 364-436.

Tomasz z Akwinu, Summa theologiae.

Tomasz z Akwinu, Super Boetium de Trinitate.

Ks. prof. dr hab. Janusz Królikowski - kapłan diecezji tarnowskiej; w latach 2014-2020 dziekan Wydziału Teologicznego Sekcja w Tarnowie (UPJPII). Od 1997 roku wykłada teologię dogmatyczną na Wydziale Teologicznym Sekcja w Tarnowie. Od 2010 roku wykładowca mariologii w Instytucie Maryjno-Kolbiańskim „Kolbianum” w Niepokalanowie. Członek Polskiego Towarzystwa Mariologicznego, Towarzystwa Teologów Dogmatyków, Polskiego Towarzystwa Teologicznego Oddział w Tarnowie, członek zwyczajny Międzynarodowej Papieskiej Akademii Maryjnej w Rzymie. Autor licznych publikacji teologicznych. 